\title{
THE ANNUAL MEETING IN LAS VEGAS
}

The seventy-eighth annual meeting of the American Mathematical Society was held at the Sahara Hotel in Las Vegas, Nevada from Monday, January 17 through Thursday, January 20, in conjunction with the Mathematical Association of America. There were 2,757 registrants, including 2,209 members of the Society.

The forty-fifth Josiah Willard Gibbs Lecture, Missed opportunities, was given by Professor Freeman J. Dyson of the Institute for Advanced Study at 8:30 p.m. on Monday, January 17. Professor Dyson was introduced by Professor Nathan Jacobson.

By invitation of the Committee to Select Hour Speakers for Summer and Annual Meetings, there were eight invited addresses. Professor Blaine Lawson of the University of California, Berkeley, spoke on Foliations of compact manifolds. He was introduced by Professor Calvin C. Moore of the University of California, Berkeley. Professor Robert M. Solovay of the University of California, Berkeley, lectured on Powers of singular cardinals. He was introduced by Professor Mary Ellen Rudin of the University of Wisconsin. Professor Myles Tierney of Rutgers University spoke on Some applications of an axiomatic theory of sheaves. Professor Saunders Mac Lane of the University of Chicago introduced Professor Tierney. Professor Robert F. Williams of Northwestern University lectured on The structure of attractors; he was introduced by Professor Stephen Smale of the University of California, Berkeley. Professor Richard S. Palais of Brandeis University lectured on Equivariant real algebraic differential topology. Professor Morris W. Hirsch of the University of California, Berkeley, introduced Professor Palais. Professor Hugo Rossi of Brandeis University gave an address entitled On automorphism groups of induced $C R$ structure; he was introduced by Professor John Wermer of Brown University. Professor Jacob T. Schwartz of the Courant Institute of Mathematical Sciences, New York University, spoke on Complexity of statement, computation, and proof. Professor Herbert B. Keller of the Firestone Laboratory, California Institute of Technology, introduced Professor Schwartz. Professor Charles C. Pugh of the University of California, Berkeley, lectured on The closing lemma revisited; he was introduced by Professor Robert F. Williams of Northwestern University.

The Frank Nelson Cole Prize in the Theory of Numbers was awarded to Professor Wolfgang M. Schmidt of the University of Colorado on Wednesday, January 19. The prize was given in recognition of the following four papers: On simultaneous approximations of two algebraic numbers 
by rationals, Acta Math. 119 (1967), 27-50; T-numbers do exist, Symposia Mathematica (4), Istituto Nazionale di Alta Matematica, Academic Press, New York, 1970, pp. 1-26; Simultaneous approximation to algebraic numbers by rationals, Acta Math. 125 (1970), 189-201; On Mahler's T-numbers, Proc. Sympos. Pure Math., vol. 20, Amer. Math. Soc., Providence, 1971, pp. 275-286. At the award ceremony, Professor Schmidt lectured on Some recent developments in Diophantine approximation.

The Conference Board of the Mathematical Sciences presented a panel discussion on Performance Contracting and Mathematics in the Schools on Wednesday, January 19. On Tuesday, January 18, the American Mathematical Society Committee on Employment and Educational Policy sponsored a general discussion of the employment situation. A board meeting of the Rocky Mountain Mathematics Consortium was held on Thursday, January 20.

There were two special sessions of selected twenty-minute papers. A session on Harmonic Analysis on Solvable and Nilpotent Lie Groups was arranged by Professor Louis Auslander of the City University of New York and was held on Monday, January 17. Professor Morris W. Hirsch of the University of California, Berkeley, organized a session on Foliations and Stable Manifolds. This session was held on Tuesday, January 18. An informal session on Noncommutative Approximation Theory was organized by Professor Paul Halmos of Indiana University. This session also ran on Tuesday, January 18.

There were eighty-two sessions for contributed ten-minute papers. They were chaired by the following: Oliver G. Aberth, C. W. Ahlers, Clifford H. Anderson, Paul B. Bailey, Thomas F. Banchoff, Dorothy L. Bernstein, James W. Brewer, H. H. Brungs, J. Bustoz, James S. Byrnes, Ronn L. Carpenter, David R. Cecil, Paul F. Cherenack, Frederick H. Croom, R. S. Dahiya, Gene A. DeBoth, James A. Deddens, Ivan N. Erdelyi, Vance Faber, John W. Gaisser, George C. Gastl, Constantine E. Georgakis, Larry J. Gerstein, Frank L. Gilfeather, Gunther W. Goes, Charles L. Hagopian, Carl S. Hartzman, Charles M. Harvey, Stephen R. Hilbert, Mohammed Ishaq, Awad A. Iskander, Robert I. Jewett, Jerry A. Johnson, Zaven A. Karian, David C. Kurtz, William A. Lampe, Roland E. Larson, Edwin L. Marsden, Jr., Martha M. Mattamal, Edward J. Mayland, Jr., Thomas L. McCoy, Cleve B. Moler, Edward T. Ordman, Jagdish N. Pandey, Wayne R. Park, George O. Peters, Allan C. Peterson, H. LeRoy Peterson, Gideon Peyser, Roy M. Rakestraw, Marlon C. Rayburn, Jr., Alan E. Rosenberg, Donald C. Rung, Marshall Saade, Diran Sarafyan, Philip W. Schaefer, Herman E. Scheiblich, Robert Schneider, Seymour Schuster, Sanford L. Segal, Virindra M. Sehgal, Shawky E. Shamma, Hari Shankar, Harris S. Shultz, Martha J. Siegel, Ruth Silverman, William Harris Simons, John A. Suvak, George Szeto, Dov Tamari, Gary M. 
Thomas, Theodore N. Tracewell, Philip W. Walker, Hoyt D. Warner, Bill Watson, James R. Weaver, Arthur Thomas White, II, David L. Williams, Stephen James Wolfe, Robert M. Young, and Joel L. Zeitlin.

The Arrangements Committee for the meeting consisted of E. Maurice Beesley, chairman, Paul Aizley, H. L. Alder, ex officio, Michael A. Goldberg, Robert Clark Hooper, Kenneth A. Ross, ex officio, Lewis J. Simonoff, Gordon L. Walker, ex officio, and Edward F. Wishart.

The Council met on January 16, 1972 at 2:00 P.M. in Rooms 11-12 of the Sahara Hotel, with President Jacobson in the chair. It was the first meeting held in accord with newly established policy that meetings are ordinarily to be open to the membership, although visitors may not have the floor except by permission.

The Secretary announced the election of the following 160 persons to ordinary membership in the Society:

\author{
Albright, Richard A., Hobart \& Smith Colleges \\ Alendsandrov, I. A., Academy of Science-Ukrania, Donetsk, USSR \\ Altilio, Joseph John, Jr., Fordham University \\ Angwin, George T., Illinois State University \\ Axler, Sheldon J., University of California, Berkeley \\ Baclawski, Kenneth Paul, Harvard University \\ Basu, Adhir K., Laurentian University \\ Becker, Sister Patricia, Rosemont College \\ Belanger, David G., University of South Alabama \\ Belding, W. Russell, University of Notre Dame \\ Berenbom, Joshua, Polytechnic Institute of Brooklyn \\ Beyma, Severin R., Hampton Institute \\ Biroli, Marco, Via Marcona 15, Milano, Italy \\ Blackmore, Denis L., Newark College of Engineering \\ Blanco Guevara, Ernesto Aly, Venezuelan Air Force Academy \\ Boler, James, Rice University \\ Boren, Sue, University of Tennessee at Martin \\ Brown, Marianne S., Dartmouth College \\ Bruggeman, John J., IBM, San Jose, California \\ Buck, Robert Jay, University of California, Davis \\ Burns, Susan E., University of Alaska \\ Butler, Jean W., University of Washington \\ Button, Robert W., Carnegie-Mellon University \\ Cahen, Paisl-Jean, Queen's University \\ Caiha, Prabha, National Institute of Bank Management, Bombay, India \\ Chang, Elizabeth Brabson, University of Maryland \\ Chang, K. W., University of Calgary \\ Cheung, King Lai, Almart Department Store, New York, New York \\ Chin, Bang-Yaw, Desert Research Institute, Reno, Nevada \\ Choi, Shiu Lun Godfrey, University of British Columbia \\ Clover, William John Jr., Concordia Teachers College \\ Connor, Philip J., Devon Preparatory School \\ Cook, L. Pamela, Cornell University \\ Costello, F. T., Dale Engineering Company, Utica, New York \\ Cowan, John C., III., Webco Mills, Inc., Burlington, North Carolina
}


Cowens, J. Wayne, 1101 North Calvert Street, Apt. 807, Baltimore, Maryland Dana, Stephen F., Addison-Wesley Publishing, Reading, Massachusetts

Dayton, Barry H., Northeastern Illinois University

De Gonzalez, Morales Josepina, University of Puerto Rico

DeLaurentis, Matthew P., 102 South Holly Avenue, Maple Shade, New Jersey

Dellen, Donald E., Wadsworth Publishing, Belmont, California

Duncan, T. E., State University of New York at StonyBrook

Ehrlich, Paul Ewing, State University of New York at Stony Brook

Elson, Constance McMillan, Ithaca College

Fay, Temple Harold, Hendrix College

Feinerman, Robert P., Herbert H. Lehman College (CUNY)

Feldman, William Alan, University of Arkansas

Fermin, Saturnino, Polvorin A Pila No 8, Lapastora, Caracas 101, Venezuela

Flynn, Gerald, Polytechnic Institute of Brooklyn

Freeburg, Donald C., Fitchburg State College

Gaisser, John W., 416 South Alvord, Evansville, Indiana

Garbutt, Max O., Moorpark College

Gardner, Celesta Jill, Virginia Polytechnic Institute and State University

Geller, Nancy L., University of Rochester

Geman, Donald, University of Massachusetts

Giroux, Gaston, University of Sherbrooke

Grams, William F., Florida State University

Greenberg, William Indiana University

Hall, Robert E., State University of New York at Brockport

Haskins, Loren J., University of Denver

Hatta, Leiko, University of Houston

Hee, Christopher E., Eastern Michigan University

Hery, William J., Polytechnic Institute of Brooklyn

Holt, Kathleen D., University of Pittsburgh

Hrycyszyn, Joseph D., Illinois State University

Hsu, Tiao-Tiao, University of California at Los Angeles

$\mathrm{Hu}$, Ming-Kuei, Syracuse University

Hung, Henry Hin-Lai, McGill University

Immergut, Edmund H., Gordon \& Breach, New York, New York

Jensen, Don Cook, University of Waterloo

Johnson, Donald E., North Central College

Johnson, Gary M., Aerospace Research Laboratory, Wright-Patterson

AFB, Ohio

Kahane, Charles T., University of Illinois

Kapoor, O. P., Indian Institute of Technology, Kanpur, India

Kelly, David, University of Mannheim

Kelly, David, Queen's University

Kent, Michael J., University of Georgia

Kentzer, Czeslaw P., Purdue University

Khiem, Chu Duy, 194/1 Vo Di Nguy, Phy Nhuan, Vietnam

Kingman, J. F. C., University of Oxford

Kollett, Francis W., Loyola University

Kotzig, Anton, Université de Montréal

Kranzler, Stanley K., University of Hawaii

Kuzanek, Jerry F., 885 West El Repetto Drive, Apt. 46, Monterey Park, California

Langan, Thomas J., Naval Ship Research and Development, Carderock, Maryland

Langbein, Eugene G., Alphonsus College

Lathan, Calvin A., Monroe Community College 
Leavitt, Teddy C., State University of New York at Plattsburg

Lee, Robert Alec, State University of New York at Buffalo

Lim, Chong-Keang, University of Malaya

Lue, Huei-Shyong, University of Notre Dame

Machuca, Raul G., Monterrey Institute of Technology

Macri, Nicholas, Temple University

Matas, Margarita M., Herbert H. Lehman College, City University of New York

Mazaitis, George, Adelphi University

McClellan, David Bruce, 12 Forest Drive, Albany, New York

McCrevan, George Patrick, Jr., 50 Saint Agatha Road, East Milton, Massachusetts

McCutchson, Thomas R., University of California at Los Angeles

Meyer, Robert L., California State College at Los Angeles

Moreman, Douglas, Auburn University

Moulis, Edward J., Jr., Frostburg State College

Mureika, Roman A., University of Alberta

Nash, David, University of California at Berkeley

Neimann, Albert A., Federal Government, Concord, California

Nguyen Cao, Dam, University of Cantho, South Vietnam

Oba, Marilyn K., Loyola University of Los Angeles

O'Boyle, James Nicholas Jr., University of Maine

Pacholke, Kenneth, University of Colorado

Page, Warren, New York City Community College, City University of New York

Pankin, Mark D., University of Iowa

Pelles, Donald Alfred, University of South Carolina

Perlmutter, Dianne Haber, Northeastern University

Peyovitch, T. Z., University of Belgrade

Phillips, David George, Wappingers Falls Central School District

Pickorides, Stylianus, 11 Irakleous Street, Athens, Greece

Pinker, Aron, Frostburg State College

Poole, William G., Jr., College of William \& Mary

Pound, Lelia D., 5526 East 65th Place, Tulsa, Oklahoma

Purdy, Michael G., Valparaiso University

Ramkissoon, Harold, University of Alberta

Rant, William, 705 North Church Street, Jacksonville, Alabama

Rawson, Freeman, L., III., Stanford University

Riedlinger, Roy F., Mankato State College

Riess, R. D., Virginia Polytechnic Institute and State University

Ronveaux, Andre, University of Notre Dame de la Paix, Brussels, Belgium

Rothbart, Andrea May, California State College, Bakersfield

Schapira, Michael Jay, Brooklyn College, City University of New York

Schumacher, Dietmar, Acadia University

Schumacher, Leif A., 5400 Pooks Hill Road, Apt. 817, Bethesda, Maryland

Schumaker, Larry L., University of Texas at Austin

Selesnick, Stephen Allan, Louisiana State University

Sewell, Michael J., University of Reading

Shenkin, Peter, John Jay College, City University of New York

Shepherd, Roger A., 8332 Imperial Drive, Laurel, Maryland

Shih, Chao-Dung, University of Houston

Shriver, Bruce D., State University of New York at Buffalo

Siegel, Jerrold N., University of Missouri at St. Louis 
Silvers, Dixie L., University of Northern Colorado

Singer, David Allen, Cornell University

Singer, Ivan J., University of California at Los Angeles

Straley, William, Auburn University

Stratigos, Peter D., Long Island University

Streit, Ronald F., Texas Technological University

Stubblefield, Beauregard, Institute for Services to Education, Washington, D. C.

Suarez, Pedro A., Loyola University of Chicago

Swanson, Richard E., Bentley College

Szabo, Manfred Egon, Sir George Williams University

Textor, Robin E., University of South Carolina

Thomas, Kenneth E., University of Nebraska

Tippett, James M., University of Kentucky

Todd, Aaron P., University of Florida

Tuchinsky, Philip M., Kalamazoo College

Ungar, Avraham, University of Waterloo

Venugopalkrishna, U., University of Miami

Volger, Hugo, McGill University

Vuilleumier, Monique, Ohio State University

Windeknecht, Thomas G., Michigan Technological University

Wohl, Philip R., Cornell University

Wolfe, Carvel S., United States Naval Academy, Annapolis, Maryland

Zaita, Aurel J., University of Zambia

It was announced that the following persons have been elected to membership in the Society in accordance with various reciprocity agreements:

Australian Mathematical Society: John Newsome Crossley, Geoffrey Lewis. Deutsche Mathematiker-Vereinigung e.V.: Henning Esser.

London Mathematical Society: P. J. C. Lamont, Donald B. McAlister,

J. D. Maitland Wright.

Mathematical Society of Japan: Takeshi Matsuura, Shoji Watanabe.

Norsk Matematisk Forening: Steiner Magne Hveberg, Arne Stray.

Real Sociedad Matematica Española: Antonio De Castro, Juan Llovet.

Schweizerische Mathematische Gesellschaft: Jean-Pierre Schellhorn.

Societe Mathematique de France: Raymond C. Barre, Rene Jean Benlian,

Jean Raymond Genet.

Svenska Mathematikersamfundet: Torbjorn Hedberg, Martin G. Ribe.

Unione Matematica Italiana: Antonio J. Brandao Lopes Pinto.

The following persons have been elected to membership in the Society upon nomination of institutional members as indicated:

University of Alabama in Birmingham: Alice Fleming Lott, A. J. Mims,

Travis B. Wood.

Andrews University: R. Lewis Caviness, Bettye L. Nichols.

Bates College: John F. O'Hara, David A. Riffelmacher, Lucinda K. Taylor.

Berea College: Rita Yvonne Hopkins, Dennis Strickler.

Boston State College: John R. Nee, William E. Perrault, Richard D. Truesdell.

University of Bridgeport: Helen $\mathrm{H}$. Hu, Joseph Venditti. 
Bucknell University: David Finkel, Kenneth S. Kaminsky, D. Paul Souders

Carnegie-Mellon University: Patric L. Hayes, A. Ian Murdoch, Gregory

L. Naber, George Joseph Schiavone, Myron M. Sussman.

Catholic University of America: John E. August, Eduardo A. Luna, David

C. Mayne, Richard O. Pellerin.

Connecticut College: Walter F. Brady.

University of Delaware: John F. Ahner, John D. Anderson, John J. Avioli.

University of Denver: Mark J. Balas, Dexter Strawther.

Florida State University: Paul M. Cook, James K. Deveney, Richard A.

Gayley, Joseph F. Hoffmann, Francis A. Muscato, William A. McCallum,

Byron Smith, III, Roger L. Taylor.

University of Georgia: William S. Owen, Jr.

Middlebury College: Robert Goodsell, Frederick Tinsley.

University of Missouri at Rolla: Karen Carter.

Newberry College: Nathan Kibler Williamson.

Northeastern Illinois University: Kim Castagna.

Polytechnic Institute of Brooklyn: William J. Amadio.

Reed College: William A. Adkins.

Rockefeller University: Pierre L. J. Van Moerbeke.

San Fernando Valley State College: James V. Anderson, Charles Frank

Peters, Jerry Morris Karl, Christine Spengel.

University of Washington, Seattle: Rebecca R. Kitto.

University of Wisconsin: Roy W. Pengra.

Worcester Polytechnic Institute: Barry M. Moran.

Worcester State College: Vito D. Campo, Anthony M. Devoe, John C. Hayes.

It was noted that President Jacobson had established committees and had made appointments to committees as follows:

Committee to Select Hour Speakers for Southeastern Sectional Meetings: Trevor Evans

Committee to Select Hour Speakers for Far Western Sectional Meetings:

Charles J. Stone

Committee to Select Hour Speakers for Summer and Annual Meetings: Frederick W. Almgren, Daniel Gorenstein, William H. Reid, GianCarlo Rota

Committee to Select Hour Speakers for Western Meetings: Daniel Zelinsky

Committee in Aid to Pakistani Refugee Mathematicians: Paul T. Bateman, John L. Kelley, Chairman, Ram Prakash Kanwal

Committee on Relations with Government: Garrett Birkhoff, Felix E. Browder, R. Creighton Buck, John W. Jewett, George D. Mostow, Lowell J. Paige, Chairman

Committee on Nominating Procedures: Murray Gerstenhaber, Chairman, Paul R. Halmos, Victor L. Klee, Jr.

Committee on Women in Mathematics: Mary W. Gray, I. N. Herstein, Cathleen S. Morawetz, Chairman, Charles B. Morrey, Jr., Jane Cronin Scanlon 
Committee on Steele Prizes: Chen Chung Chang, Murray H. Protter, Chairman, Robert Steinberg

Committee on Arrangements for 1972 Annual Meeting in Las Vegas: Paul Aizley, Henry L. Alder, ex officio, E. Maurice Beesley, Chairman, Michael A. Goldberg, Robert Clark Hooper, Kenneth A. Ross, ex officio, Lewis, J. Simonoff, Gordon L. Walker, ex officio, Edward F. Wishart Committee on Arrangements for 1972 Summer Meeting at Hanover: H. L. Alder, ex officio, Mrs. Sandi J. Garland, K. I. Gross, Chairman, Walter Gottschalk, ex officio, R. T. Prosser, W. E. Slesnick, G. L. Walker, ex officio, H. D. Weed

Tellers for the 1971 Election: Ruth M. Hailperin, Doris W. Schattschneider.

It was recorded that the following persons represented the Society at various functions:

David G. Bourgin at the Inauguration of Norman Hackerman as President of William Marsh Rice University, Houston, Texas

Nevin W. Savage at the Inauguration of John Paul Schaefer as President of the University of Arizona, Tucson, Arizona

Richard F. Johnsonbaugh at the Inauguration of Ward Pafford as President of West Georgia College, Carrolton, Georgia

Howard Sherwood at the Inauguration of John Edwin Johns as President of Stetson University, DeLand, Florida

C. Edmund Burgess at the Inauguration of Dallin Harris Oaks as President of Brigham Young University, Provo, Utah

Hussein A. Elkholy at the Inauguration of Edward J. Bloustein as President of Rutgers, the State University, New Brunswick, New Jersey.

The following persons have accepted invitations to give hour addresses at the times and places noted:

James B. Ax

David A. Buchsbaum

Alex Rosenberg

Gian-Carlo Rota

Gilbert Baumslag

Allen Devinatz

Larry Markus

Wolfgang Schmidt

Atle Selberg

Roger Richardson

Joseph L. Taylor

Peter L. Crawley

Donald E. Sarason
New York

New York

New York

New York

St. Louis

St. Louis

St. Louis

St. Louis

St. Louis

Berkeley

Berkeley

Seattle

Seattle
March 1972

March 1972

March 1972

March 1972

March 1972

March 1972

March 1972

March 1972

March 1972

April 1972

April 1972

June 1972

June 1972 
The Secretary reported on the result of the election of 1971 . The result has subsequently been published on p. 288 of this volume of the Bulletin.

The Council elected William Browder and F. W. Gehring to positions on the Executive Committee.

The Council set the time and place of the next three Council meetings as follows:

$\begin{array}{ll}\text { St. Louis } & \text { Friday, March 31, 1972 } \\ \text { Hanover } & \text { Tuesday, August 29, 1972 } \\ \text { Dallas } & \text { Wednesday, January 24, 1973 }\end{array}$

The Committee on a Comprehensive Subject Index for Mathematics presented a report. The major recommendation was the following:

We recommend that the Society undertake the periodic publication of a subject index of the current mathematical literature, covering all items appearing in Mathematical Reviews. While the Society's commitment should be reassessed after a suitable period of time, the continuation of this publication should not depend solely on that of the Mathematical Offprint Service; at the same time, procedures should be planned so as to make every possible use of activities already carried out by MOS as well as those to be instituted in connection with MR author indexes. We further recommend that subject indexes not be attempted before it has been demonstrated through successful production of MOS [now MTS, namely Mathematical Title Service] and MR cumulative author indexes that the Society has the necessary machine capability, as well as the trained personnel in both Providence and Ann Arbor.

The recommendation was approved, together with several subsidiary procedural recommendations. It was understood that the new fine classification developed for the Mathematical Offprint Service, as published in the Mathematical Reviews index number for volume 39, would be used.

The Council passed a resolution viewing with approval the efforts being made greatly to increase the coverage of applied mathematics in Mathematical Reviews. They also approved a proposal to sell subscriptions to portions of Mathematical Reviews as well as subscriptions to all of the journal.

The Council considered at length a proposal to enable nominations by petition for positions of member-at-large of the Council but finally referred the matter back to the Committee on Nominating Procedures. 
The Council established an Editorial Committee for the journal Contents of Contemporary Mathematical Journals, into which the journal New Publications was recently merged.

The Council received a report by R. D. Anderson, Chairman of the Committee on Employment and Educational Policy. The report was subsequently published in the Notices for March 1972.

The Council authorized Society participation, jointly with others, in sponsorship of a session of contributed papers in the area of Bio-mathematics and Theoretical Biology at the meeting of the American Association for the Advancement of Science in December 1972 in Washington.

The Council adjourned at 6:30 P.M.

The President convened the Business Meeting at 2:45 P.M. in Rooms 2 and 3 of the Sahara Hotel Convention Center.

Professor Paul Bateman announced that the Society was receiving contributions to the Fund for Resettlement of Bangladesh Mathematicians.

The Secretary reported on recent actions of the Council of interest to the membership.

In accordance with Article X, Section 1, of the bylaws, the following resolution was on the agenda of the Business Meeting:

(1) the American Mathematical Society will work actively for equal opportunities for women in the following areas:

(a) employment at all levels: this will include the search for and recruitment of qualified women

(b) advancement and tenure in academic positions

(c) admissions to graduate schools

(d) graduate and postdoctoral fellowship and assistantships

(e) membership on advisory boards and panels and

(2) the Society will include more women on

(a) Society programs and panels, including invited speakers and section chairmen.

(b) Society committees and governing boards.

After brief discussion, the resolution was passed.

Professor E. E. Moise introduced a resolution formulated by the Mathematicians Action Group and reading as follows:

Resolved, that this meeting urges the Council of the Society to address itself with greater vigor to various problems now facing the mathematical community. These include the following.

(1) The status of women in the profession, and in various of the Society's working committees, and the status of various ethnic minority groups.

(2) The economic status of the profession, and the relation of the 
profession to the colleges and universities and to society in general.

These include long range problems, and there is no reason to expect that the best efforts of anyone could solve them immediately. But the Society should attack them as best it can; we should not regard ourselves merely as spectators. Meanwhile there is a short-range problem which allows an immediate solution. Provision should be made, with no further delay, for candidates for Council membership to be placed on the ballot by petition, without any further screening either by the Council or by the nominating committee.

Following extended discussion, including a ruling that passage of the resolution was in order because it was advisory and did not constitute "final action" in the sense of Article X, Section 1, of the bylaws, the resolution was passed.

The meeting adjourned at 3:55 P.M.

Bethlehem, Pennsylvania

Everett PITCHER Secretary

EUGENE, OREGON

KENNETH A. Ross

Associate Secretary

\section{THE MARCH MEETING IN NEW YORK}

The six hundred ninety-second meeting of the American Mathematical Society was held at the Biltmore Hotel in New York, New York, from Monday, March 27, through Thursday, March 30, 1972. There were 366 registrants including 307 members of the Society.

By invitation of the Committee to Select Hour Speakers for Eastern Sectional Meetings, there were four one-hour addresses. Professor James B. Ax of the State University of New York at Stony Brook spoke on Some topics in differential algebraic geometry; he was introduced by Professor Hyman Bass. Professor David A. Buchsbaum of Brandeis University spoke on Complexes, ideals, resolutions; he was introduced by Professor Alex Heller. Professor Alex Rosenberg of Cornell University spoke on Commutative ring theory and the structure of Witt rings; he was introduced by Professor Carl Faith. Professor Gian-Carlo Rota of the Massachusetts Institute of Technology spoke on Combinatorial theory; he was introduced by Dr. Alan J. Hoffman.

There were eighteen sessions for contributed ten-minute papers, chaired by Dr. Tadatoshi Akiba, Professors George Bachman, Donald Cook, Peter M. Curran, Robert Delver, Mr. Richard F. Freund, Professors Ter-Jeng Huang, John S. Kalme, Luise-Charlotte Kappe, Michael J. Kascic, Jr., Gary B. Laison, Elliott Mendelson, Eileen L. Poiani, Mr. John Riordan, Professor Jane Cronin Scanlon, Dr. Lawrence A. Shepp, Professors Leon Steinberg, and Donald R. Wilken. 